\title{
O LINCHADO E A PRODUÇÃO DO CORPO CRIMINOSO
}

\author{
GUILHERME FERRAGUT ${ }^{1}$
}

Instituto de Estudos da Linguagem (IEL), Unicamp

guilherme ferragut@hotmail.com

\begin{abstract}
Resumo. Em 3 de maio de 2014, a dona de casa Fabiane Maria de Jesus, 33 anos, foi linchada no bairro Morrinhos 4, no Guarujá, Estado de São Paulo. Este trabalho tem como objetivo tratar do processo de discursivização do linchamento como acontecimento através da Análise de Discurso de linha francesa, que encontra Michel Pêcheux como fundador e Eni Orlandi como representante de tal filiação no Brasil. Como significa o ato de linchar? Através da Análise de Discurso, como os sentidos significam o corpo linchado? Estas são algumas das questões que serão problematizadas, produzindo sobre elas gestos de interpretação.
\end{abstract}

Palavras-chave: linchamento; Guarujá; Análise de Discurso.

\begin{abstract}
On May 3, 2014, housewife Fabiana Maria de Jesus, 33, was lynched in the Morrinhos 4 neighborhood in Guarujá, State of São Paulo. This paper aims to deal with the process of discursivization of lynching as an event through French discourse analysis, which has as founder Michel Pêcheux and Eni Orlandi as the main representative in Brazil. What does the act of lynching mean? Through Discourse Analysis, how do the senses mean the body lynched? These are some of the issues that will be problematized, producing gestures of interpretation.
\end{abstract}

Keywords: lynching; Guarujá; Discourse Analysis.

\section{INTRODUÇÃO}

Ao pensarmos nos casos de linchamento, questionamos a possibilidade do corpo do linchado ser a materialidade do discurso de quem pratica a ação. Assim como a língua pode ser entendida como materialidade específica do discurso (ORLANDI, 2016, p. 83 e 84), poderíamos considerar o corpo do linchado outra forma de materialidade desse discurso? Para respondermos à pergunta traremos algumas considerações de Orlandi.

Inicialmente trataremos da relação corpo e sujeito. Para tal, seguindo os passos da autora (ORLANDI, 2016), buscaremos explicitar como se dá essa relação. Sendo assim, a autora parte da materialidade discursiva para juntar corpo, sujeito e sentido. Citando Pêcheux, Orlandi explica que língua e ideologia, assim como ideologia e inconsciente, estão materialmente ligados de acordo com a teoria da Análise de Discurso. Dessa forma, ao pensarmos a interpelação do indivíduo em sujeito temos a questão da materialidade.

\footnotetext{
${ }^{1}$ Doutorando em Linguística na Universidade Estadual de Campinas.
} 
A materialidade do sujeito dá-se pela não transparência. "É na questão da materialidade do sujeito que está a negação do sujeito como origem quer de si, quer dos sentidos" (ORLANDI, 2016, p. 84). Em seguida, Orlandi trata dos discursos, que por efeito da materialidade da ideologia, acabam por parecer estar sempre lá. Para concluir, a autora afirma a não separação entre sujeito e objeto através do materialismo histórico, questão abordada por Pêcheux em sua teoria fundadora. E conclui: "não podemos pensar o sujeito, nessa perspectiva, sem a ideologia, e a ideologia sem a materialidade, a história e os processos da vida social e política" (ORLANDI, 2016, p. 85). Temos assim, como se dá a relação corpo e sujeito. Ou seja, "enquanto corpo simbólico, corpo de um sujeito, ele é produzido em um processo que é o processo de significação, onde trabalha a ideologia, cuja materialidade específica é o discurso" (ORLANDI, 2016, p. 85).

A autora também afirma que "corpos investidos de sentidos, na materialidade dos sujeitos, textualizam-se" (ORLANDI, 2016, p. 86). Exemplos dessa textualização seriam o piercing e a tatuagem. Assim como a língua, materialidade específica do discurso, produz um texto, o corpo, materialidade do sujeito, é capaz de se textualizar através de algumas marcas. Dessa forma, poderíamos dizer que, embora involuntariamente, ao contrário do que acontece quando um sujeito resolve colocar um piercing ou fazer uma tatuagem, as marcas da violência no corpo do linchado também textualizariam seu corpo, estabelecendo formulação e circulação de sentidos em seus efeitos.

Tendo a teoria da Análise de Discurso como base, compreendemos que os sentidos não dependem do sujeito e escapam ao seu querer, à sua vontade, pois são determinados pelo modo como se inscrevem na história, ou seja, pelo modo como são historicamente significados. Esse modo de significação histórica dos sentidos é o que chamamos de memória discursiva. Conforme Pêcheux (2010) define, memória discursiva é concebida numa esfera social e coletiva, ao contrário das lembranças pessoais. É a memória discursiva a responsável por produzir as condições para que o discurso funcione como rede de filiação de sentidos. Pêcheux (2010) nos explica que há um embate entre a memória discursiva e o acontecimento discursivo. Enquanto a primeira busca reestabelecer e estabilizar implícitos, o segundo insiste em perturbar e desregularizar os implícitos. É nessa disputa que temos novos sentidos para ultrapassam o já-dito da memória (interdiscurso).

Cabe aqui recorrermos à reflexão de Martins (2015) para compreendermos alguns elementos da constituição dos linchamentos. Conforme Martins (2015) descreve em seu livro, linchamentos vêm acontecendo no Brasil há muito tempo, sendo que seus primeiros registros datam ainda do século XVI. E cabe ressaltar que está longe de ser exclusividade brasileira. Porém, devido às condições de produção de tal discurso (linchamento), ele pode ser interpretado de maneiras diferentes em cada lugar e em cada período.

Enquanto nos Estados Unidos, por exemplo, os linchamentos têm brancos linchando negros para "ensinar" qual o lugar do outro na sociedade, no Brasil tais atos são de outra ordem. Conforme explica o autor já citado, esse tipo de violência em terras brasileiras trata mais de um reestabelecimento de uma ordem supostamente perdida do que de uma questão de raças. Para embasar tal pensamento, Martins afirma que há negros participando do linchamento de negros, por exemplo. A questão brasileira diz respeito ao restabelecimento de um sentido para a comunidade que pratica o ato. Como se alguém de fora dessa sociedade tivesse "sequestrado" a segurança que se acreditava ter e coubesse à 
própria comunidade resgatá-la (a segurança). Quando trazemos a expressão "alguém de fora da sociedade", queremos dizer que ao se tornar alvo de um linchamento ou tentativa, o sujeito que sofre a violência é considerado um estranho. $\mathrm{O}$ crime que se atribui ao linchado faz com que ele seja considerado um sujeito que não pertence mais à comunidade onde mora. Torna-se um corpo banido. Trataremos detalhadamente deste processo mais adiante.

É importante lembrar que os sentidos podem ser muitos, mas não são infinitos. Isso porque cada discurso está inserido numa formação discursiva, onde a materialidade histórica é determinante (ORLANDI, 2016). Sendo assim, ao pensarmos o caso do corpo linchado, inserido na formação discursiva "bandido bom é bandido morto", por exemplo, as marcas de violência infligidas à vítima tentam estabilizar este sentido. Afinal, se o bandido bom é o bandido morto, por que ele estaria andando sossegadamente pela comunidade? De que adiantaria chamar a Polícia e entregá-lo ao invés de linchá-lo se a Justiça não tem punições severas o suficiente para matá-lo como querem os sujeitos que se filiam ao discurso do bandido bom é bandido morto?

Podemos ir além. Ao pensarmos na possibilidade de dizer "bandido bom é bandido morto" passamos pela descrença na Justiça como forma eficiente de punição aos crimes praticados. Mas é preciso colocar tal fala em sua devida condição histórica de produção. Em dado momento, após a Idade Média, afirma Foucault (2015), “o sistema penal teve por função opor os plebeus proletarizados e os plebeus não proletarizados" ( $p$. 103). Para tal, fez com que

a plebe não proletarizada aparecesse aos olhos do proletariado como marginal, perigosa, imoral, ameaçadora da sociedade inteira, a escória do povo, o rebotalho, a "gatunagem"; trata-se para a burguesia de impor ao proletariado, pela via da legislação penal, da prisão, mas também dos jornais, da "literatura", certas categorias da moral dita "universal" que servirão de barreira ideológica entre ela e a plebe não proletarizada; toda figuração literária, jornalística, médica, sociológica, antropológica do criminoso desempenha esse papel. (FOUCAULT, 2015, p. 104)

Com isso, podemos dizer que o "bandido bom é bandido morto" aparece após uma "construção" arquitetada pela burguesia para transformar a plebe não proletarizada no inimigo do proletariado. Dessa forma, tendo que ser eliminada em favor de uma moral dita "universal". Sendo assim, tentamos contextualizar de onde vem a ideia de que aquele que não tem emprego acaba como culpado por crimes que por vezes não cometeu.

Postas as considerações acima, ainda persistem algumas perguntas como: de onde partiria a ideia de violência contra aquele que não se encontra incluído na mesma comunidade que quem agride? Freud (2013) pode fornecer algumas respostas sobre o assunto. Para começar, precisamos entender o que mantém a massa coesa na hora de uma ação violenta como o linchamento. $\mathrm{O}$ autor afirma que "as relações amorosas (ou, para empregar expressão mais neutra, os laços emocionais) constituem também a essência da mente grupal" (FREUD, 2013, p. 15). E continua, "o ódio contra uma determinada pessoa ou instituição poderia funcionar exatamente da mesma maneira unificadora e evocar o mesmo tipo de laços emocionais" (FREUD, 2013, p. 20). 
Estando os agressores unidos pelo ódio ao que vem de fora de sua sociedade, o próximo passo seria entender o porquê da agressão. Cabe aqui uma retomada do que foi dito mais acima. Isso porque, ao afirmarmos que o ódio da turba é dirigido a quem vem de fora, não necessariamente isso indica que de fato o agredido é alguém de outra comunidade. Conforme veremos na explicação de Girard (1985), o que acontece é que no momento em que é imputado um crime a alguém, este torna-se um estranho, fora dos padrões, a escória do povo, como disse Foucault (2015). Retornaremos a este tema mais abaixo.

Por agora, vamos nos ater a outro ponto. Conforme afirma Martins (2015), para que a população tome o sentido de justiça nas próprias mãos é preciso que ela desacredite no julgamento formal, utilizando de instituições do Estado. É preciso que ela acredite que "o Sistema Jurídico está falido". De acordo com o autor, essa "ideia" é construída pelas informações que os meios de comunicação trazem à população. Em outras palavras, o que ele afirma é que o descrédito de que tal instituição sofre cabe em parte às notícias que os jornais publicam sobre ela.

Vale ressaltar que quando são usadas as palavras bandido e criminoso neste trabalho é sempre pelo olhar de quem lincha. Isso porque na sociedade capitalista moderna, onde se constitui o sujeito-jurídico ${ }^{2}$, tal afirmação só poderia ser feita após um julgamento formal, em todas as instâncias possíveis dentro da Justiça. Sendo assim, o linchamento também pode ser considerado um tribunal de rua.

Quando falamos em tribunal de rua é possível estabelecer uma certa relação com a barbárie. Isso porque o julgamento formal, aplicado pelo Estado, teria componentes, por exemplo, ditos isentos e legitimados para realizar a condenação ou a absolvição de um réu. Sendo assim, poderíamos afirmar que de certa forma o tribunal de rua causa um rompimento com o jurídico, faz emergir a voz da massa, e com isso causa deslocamentos no próprio sentido de Justiça. Não há chance de absolvição. O suspeito é sempre culpado. E, por vezes, quem tentar defendê-lo acabará sofrendo a mesma punição imputada à vítima da turba.

Ainda assim, cabe aqui uma breve análise das condições de uso das palavras bandido e criminoso. Numa consulta ao dicionário, podemos verificar que o verbete bandido é definido como "indivíduo que pratica assalto a mão armada; salteador; malfeitor" (FERREIRA, 1993). Já a palavra "criminoso" tem seu significado numa formação discursiva da Justiça. Isso pode ser observado com a definição de criminoso como "aquele que infringe leis, o código penal, cometendo infrações ou crimes" (FERREIRA, 1993). Porém, no uso midiático das duas palavras o sentido que se procura estabilizar é o mesmo. As duas manchetes tratam de roubo de carro. Na primeira, "Criminoso é preso após roubar carro em Gravataí" (REPORTER, 2016), lê-se que um homem de 24 anos foi preso em flagrante dirigindo um carro roubado. Na segunda, "Bandido é preso após roubar carro no Rio de Janeiro" (R7, 2016) a notícia apresentada é muito semelhante, mudando a idade do preso, que neste caso tem 32 anos, e a cidade onde aconteceu o crime, no caso, o Rio de Janeiro.

\footnotetext{
2 “a forma histórica do sujeito moderno é a forma capitalista caracterizada como sujeito jurídico, com seus direitos e deveres e sua livre circulação social. As formas de individu(aliz)ação do sujeito, pelo Estado, estabelecidas pelas instituições e discursividades, resultam assim, em um indivíduo ao mesmo tempo responsável e dono de sua vontade, com direitos e deveres e direito de ir e vir" (ORLANDI, 2016, p. 228).
} 
Ao olharmos mais atentamente, percebemos que, a exemplo do que acontece nos casos de linchamento, os meios de comunicação analisados, ao formular criminoso ou bandido também realizam um pré-julgamento dos indivíduos presos. Isso porque, uma vez que ainda não houve julgamento, mesmo tendo sido presos em flagrante, nenhum deles poderia ser chamado de bandido ou criminoso. Mas com o uso recorrente dessas palavras em diversas matérias, equivale-se um termo ao outro, e equivale-se um termo a um fazer: condenar, levando a crer já serem culpados do crime pelo qual foram detidos. Sendo assim, mesmo a palavra "criminoso" estando estabilizada pelo dicionário na formação discursiva da Justiça, seu sentido é deslocado e utilizado em outras formações, como por exemplo, a midiática, tal como pudemos verificar no parágrafo acima.

Esse mesmo discurso que julga antes da Justiça traz a vontade de um julgamento mais rápido, tão rápido que o próprio meio que divulga um crime já traz a denominação do suspeito antes do julgamento: bandido, criminoso. Em outras palavras, ao chamar o suspeito de criminoso ou bandido, o jornal acaba por transparecer uma suposta ineficácia do sistema judiciário: "a justiça está falida".

O que buscamos mostrar no trecho acima é que a própria mídia toma o lugar da Justiça do Estado, ao estabelecer os adjetivos a quem foi detido, antes mesmo que eles pudessem ser julgados. Tal ato evidencia uma suposta lentidão jurídica, que acaba por fazer do jornal um tribunal tão ansioso quanto aquele formado pelos linchadores. $\mathrm{O}$ fato de colocar as palavras bandido ou criminoso numa manchete antes do julgamento dos detidos faz com que a demora nos julgamentos fique ainda mais transparente.

Retomando o foco nos linchamentos, observamos que as formas de punição usadas nestes justiçamentos populares já foram as adotadas pelo Estado em outras épocas no Brasil e continuam sendo em alguns países. Um exemplo a ser citado no caso brasileiro é a punição que recebeu Tiradentes, um dos membros da Inconfidência Mineira, que foi enforcado e teve seu corpo esquartejado e as partes espalhadas por algumas cidades do Brasil. Tais execuções eram feitas em praça pública, na frente da população, e servia como aviso para tentar inibir que atitudes como as do punido acontecessem novamente. Era como se o executado servisse de exemplo aos demais, evitando a repetição dos crimes. Tais práticas deixaram de ser adotadas pelo Estado com a Proclamação da República.

Como trata Foucault em Vigiar e Punir (1987), na sociedade ocidental tal punição corporal foi substituída pela privação do convívio social, ou mesmo por punições físicas em ambiente reservado, deixando de lado a espetacularização. Mesmo assim, é possível pensar que a função da pena a que é submetido o criminoso ainda é a mesma, uma espécie de controle social, uma vez que dentro das prisões quase que invariavelmente não há reabilitação e o egresso do sistema prisional continua estigmatizado como aqueles que eram submetidos ao escárnio público.

Para entender tal transição, do espetáculo da punição para o ambiente reservado das prisões, temos o corpo como "mergulhado num campo político" (FOUCAULT, 1987, p. 26). Como propõe o autor, "as relações de poder têm alcance imediato sobre o corpo; elas o investem, o marcam, o dirigem, o suplicam, sujeitam-no a trabalhos, obrigam-no a cerimônias, exigem-lhe sinais" (idem). Desta forma, ainda embasados pelo mesmo autor, entendemos que a mudança de punição aos criminosos tem relação direta com o novo 
poder instituído entre os séculos XVIII e XIX: a ciência. A inserção do saber científíco passa diretamente pelas formas de punição instituídas após esse período. Uma série de outros profissionais entram no âmbito da justiça, como "psicólogos, magistrados da aplicação das penas, educadores" (FOUCAULT, 1987, p. 24). Mas tais intervenções não atenuam a questão política do corpo. Ele continua sendo o alvo das ações de punição. Porém, com a entrada de um método científico na imputação da sentença e de seu cumprimento, a questão política foi silenciada. Como podemos observar em outras áreas onde a ciência se coloca como legitimadora, também no caso da justiça sua entrada acaba por apagar o político envolvendo o corpo e sua punição. Mas não podemos esquecer, a tecnologia utilizada na justiça não passa de um de seus instrumentos.

Um outro ponto importante que toca diretamente o trabalho que estamos desenvolvendo é a questão da verdade. Conforme expõe Foucault (1987), "um suplício bem-sucedido justifica a justiça, na medida em que publica a verdade do crime no próprio corpo do suplicado" (p. 62). Porém, a justiça moderna tem outras questões que não a verdade a ser desvendada. Ela está mais preocupada com as causalidades da ação criminosa e a "recuperação" do criminoso. Com isso, entendemos que ao linchar o que se busca é a verdade do crime que se acredita que o linchado cometeu. Podemos considerar a verdade como a transparência do sentido, um unívoco sobre o crime que resultou no linchamento. Ao contrário do que acontece em tribunais e prisões, nos justiçamentos populares a verdade está impressa no corpo do (in)justiçado. Não há dúvidas sobre seu crime e a aplicação de sua pena.

\section{FORMA-SUJEITO CAPITALISTA}

Para a Análise de Discurso francesa, como explica Orlandi, "a ideologia não é " $x$ " mas o mecanismo de produzir " $x$ "" $(2012$, p. 30$)$. Ou seja, tal teoria trabalha com a ideia de que a ideologia não é a ocultação da realidade, mas sim produtora de evidências, relacionando, através do imaginário, o sujeito e suas condições materiais de existência.

Em outro texto, a mesma autora diz que é preciso pensar a interpelação do indivíduo em sujeito pela ideologia, no simbólico, constituindo a forma-sujeito-histórica. E a forma-sujeito moderna é a capitalista, cuja característica é o sujeito jurídico, com seus direitos e deveres e sua livre circulação social (ORLANDI, 2016).

Porém, vale a pena pensar como tal sujeito é capaz de "esquecer" os direitos e deveres para cometer o ato de linchar. Podemos dizer que o sujeito que lincha não "esquece" da ideologia, mas sim que linchar é um efeito da falha no ritual dessa mesma ideologia capitalista. É seu direito tirar a vida de quem cometeu um crime, assim como é seu dever manter a ordem. Portanto, linchar é uma das formas de ser do sujeito jurídico. Isso porque, tendo como um de seus primados a propriedade privada, caso o Estado não consiga protegê-la, cabe ao sujeito executar a tarefa.

Ainda tratando da ideologia, é preciso ter em mente que, segundo Pêcheux, "a ideologia é um ritual com falhas" (1999, p. 13). Mas quais seriam as falhas quando falamos de linchamento? Pensamos que a ideologia faz o sujeito acreditar e agir como um sujeito de direitos e deveres, sem questionar sua liberdade e submissão. Então, ao linchar, ele age à revelia dessa ideologia. A ideologia continua funcionando, mas às 
avessas, na falha do ritual, quebrando a relação Direito/Dever, colocando esse par noutro lugar em detrimento da Justiça.

\section{O LINCHAMENTO NO GUARUJÁ}

Fabiane Maria de Jesus tinha feito compras num minimercado em Morrinhos 4, subdivisão de um bairro com o mesmo nome no Guarujá, quando foi linchada por um número indeterminado de pessoas do bairro (há testemunhas que estimam perto de 300 participantes), na tarde de 3 de maio de 2014 (FURTADO; JÚNIOR, 2014).

Inicialmente é preciso contextualizar as causas de linchamento no Brasil conforme Martins (2015) as aponta. O nome linchamento tem sua origem no capitão da Guerra Civil Americana Willian Lynch. Ele promovia espetáculos públicos de mutilação e tortura contra prisioneiros, índios e negros, que quase sempre terminavam na morte dos linchados. No Brasil, muito antes de ser designado como linchamento, estes atos já eram praticados. Enquanto nos Estados Unidos os linchamentos têm um perfil racista, segundo o autor, em terras brasileiras a ideia é bem diferente.

Aqui, diz Martins (2015), a intenção é sempre reinstalar uma ordem que se acredita perdida pela comunidade que pratica o linchamento. Sendo assim, é possível estabelecer relação deste pensamento com a ideia de mimetismo de René Girard (1983), e o bode expiatório. Segundo esta teoria, ao praticar um linchamento, transfere-se para a vítima todos os problemas de determinada comunidade. Sendo assim, sacrificada a pessoa, tudo volta ao normal. Se tomarmos essa ideia da perspectiva da Análise de Discurso, podemos afirmar que o bode expiatório é apontado como o desestabilizador de sentidos de certo local. No caso do Guarujá, por exemplo, a tal mulher que sequestrava crianças desestabilizava o sentido de uma comunidade onde todos se conhecem e se cuidam, o sentido de segurança estava perdido. Quando identificada, foi necessário que ela fosse posta para fora, morta, para que o sentido voltasse a ser o mesmo. Seu corpo tinha que ser banido.

Porém, para entender melhor como os sentidos se formam é preciso levar em consideração os dois esquecimentos de que fala Michel Pêcheux (1995). No esquecimento $\mathrm{n}^{\mathrm{o}} 1$ "o sujeito tem a ilusão de ser a origem do que diz, de serem os sentidos determinados por sua vontade, quando são determinados pela maneira como os sujeitos se inscrevem na língua e na história" (COSTA, 2014, p. 38). O esquecimento $\mathrm{n}^{\circ} 2$ "faz com que o sujeito esqueça que seu dizer sempre pode ser outro, pois a formação discursiva determina o que pode e deve ser dito a partir de uma posição ideológica" (COSTA, 2014, p. 38). Com isso tem-se o efeito-realidade e o efeito-sujeito (HERBERT, 1995).

Através desta definição dos esquecimentos, podemos perceber a tentativa de estabilização de sentidos que o linchamento representa. Ao punir o corpo estranho à sociedade, o sujeito que lincha esquece que o sentido de segurança que ele tem não é criado e definido por ele (sujeito), mas sim um conceito material, com historicidade, que foge da tentativa de estabilização empenhada por ele (sujeito). $\mathrm{O}$ sujeito, no caso o linchador, não é a origem de tal sentido de segurança. Assim como esquece também que há outros sentidos de justiça além daquela punição física que aplica a sua vítima. Há uma 
justiça formal, que por vezes não atua onde o linchamento ocorre, vinculada ao Estado. Mas onde estava o Estado?

Conforme afirma Orlandi (2016) o Estado funciona pela falha, seja na infraestrutura, na educação ou na segurança, como foi no caso de Fabiane. Quando ele falha, alguma coisa ocupa o seu lugar. Neste caso, os linchadores ocuparam o espaço da Justiça e da Polícia. Deram outro sentido à punição de uma "suspeita". Reestabeleceram seu sentido de segurança sem a intervenção estatal, intervenção a qual não estão acostumados. Principalmente se for a favor da comunidade. Não faz parte da rotina recorrer aos policiais, porque eles quase nunca estão lá. E, quando estão, tomam para si o papel de repressores, responsáveis por manter a pobreza, e os pobres, dentro de um espaço demarcado, impedindo sua livre circulação.

A notícia do linchamento de Fabiane correu os noticiários brasileiros causando grande comoção nacional. Entre os principais motivos desta comoção está o fato de Fabiane ser inocente, ou seja, não era ela a mulher procurada pela Polícia que teve o retrato divulgado. Cabe aqui uma análise breve sobre o sentido de culpada. No Brasil, para ser considerado culpado, é preciso ser julgado pela Justiça. Desta forma, qualquer linchamento praticado contra alguém que não tenha sido julgado é um ato contra um inocente. Nem mesmo o réu confesso pode ser chamado de culpado antes de ser julgado. Portanto, praticamente toda vítima de linchamento é inocente. Esta é mais uma forma de mostrar como o sentido se desloca. Mesmo estando o significado estabilizado dentro de uma norma jurídica, ele escapa. Uma pessoa que cometeu crime só pode ser chamada culpada após o julgamento, mas para os atores de um linchamento esta estabilização é esquecida. O sentido de culpado, para o sujeito que comete o linchamento, começa e termina no próprio sujeito, sem que seja necessário consultar qualquer lei. Para aquele que imputa a culpa, o julgamento já está feito e a punição deve ser aplicada imediatamente. Há uma necessidade em estabilizar o sentido e restaurar a segurança do local violado pelo estranho, estrangeiro, que quebrou uma rede de sentidos já-lá.

Cabe aqui discutir sobre o pré-construído de que fala Pêcheux, neste caso para a palavra segurança. Sendo assim, retomaremos a definição de interdiscurso. O autor define interdiscurso como o "todo complexo com dominante das formações discursivas" (PÊCHEUX, 1995, p. 163). Portanto, o interdiscurso coloca-se no complexo das formações ideológicas, dissimulado por toda formação discursiva, criando a ilusão de transparência do sentido formado nela (ROBERTO, 2005). Esse sentido é determinado materialmente no interdiscurso. "Em outros termos, o pré-construído é um elemento do interdiscurso re-inscrito no (intra)discurso do sujeito e caracteriza-se, pois, por ser proveniente da exterioridade, proveniência esta que é esquecida" (HANSEN, 2010, p. 4).

Sendo assim, temos o discurso de segurança sobrepondo-se ao discurso da justiça, dando a entender que a segurança deve prevalecer a qualquer preço, ainda que infringindo a Justiça. Temos, então, uma sociedade obcecada por estar segura, instalando câmeras e sensores que vigiam 24 horas. Porém, tal obsessão pode estar associada ao pré-construído da "falência da justiça", propagada pelos meios de comunicação, conforme exemplificamos acima. Dessa forma, quando pensamos a segurança, e sentimos necessidade de proteção, e, nos linchamentos, necessitamos de ação, trazemos para o sujeito um pré-construído fora dele, no interdiscurso, que mostra a incapacidade da Justiça em agir e punir bandidos e criminosos com maior eficiência e penas mais severas. 
Esse pré-construído que estimula o excesso de equipamentos de segurança é o mesmo que faz com que os meios de comunicação citados anteriormente julguem nas manchetes antes da Justiça o fazer nos tribunais.

\section{O ESTRANHO}

Conforme trata Martins (2015) o linchamento, no Brasil, não tem conotação racial, uma vez que, segundo ele, negros participam de linchamento de negros e brancos participam de linchamento de brancos. Mesmo assim, é impossível ignorar a questão do preconceito que envolve os justiçamentos populares.

O ato sacrificial, conforme descrito por Girard (1983), envolve sempre um estrangeiro, aquele que não será vingado por não ter relação social com a sociedade que pratica o ato. No caso do Guarujá, Fabiane morava no bairro Morrinhos 1 e foi agredida no bairro Morrinhos 4. Ela não pertencia ao local onde foi cometido o linchamento. Ela era a estrangeira, significada pelo silêncio, não dizia quem era, os outros é que a completavam, estabelecendo para Fabiane sentido outro que não aquele que ela desejava.

Mesmo sem dizer nada, Fabiane já significava. Conforme expõe Orlandi (1997), não é preciso falar para se significar. A fala viria da necessidade de estabilizarmos nossos sentidos na tentativa de nos significarmos sem que haja espaço para a interpretação do outro sobre nós. No caso de Fabiane não foi preciso dizer nada para que fosse colocado para ela o significado da "bruxa da internet". Seus atos o fizeram antes dela. Ao passar a mão sobre a cabeça da criança e oferecer-lhe uma fruta, para quem acompanhava o acontecido, ela estava aliciando uma nova vítima. Não houve tempo para que ela tentasse se significar de outra forma. O sentido já estava circulando. Percebemos que o gesto de oferecer a fruta a uma criança traz a memória da bruxa que oferece a maçã à Branca de Neve no conto de fadas. Portanto, podemos dizer que é pelo interdiscurso da bruxa má que se desencadeia a condenação e a sentença de morte. Esse é o acontecimento desencadeador, associado à possível semelhança física com o retrato falado e ainda, pelo fato de ser uma estrangeira, como apontamos acima.

Voltando a Martins (2015), os casos de linchamento ocorrem geralmente nas cidades e na maioria das vezes na periferia. Tais áreas, de acordo com a pesquisa realizada por ele, por terem custos menores, são o destino quase certo de quem chega à cidade vindo do campo, por exemplo. No caso de São Paulo, capital do Estado que leva o mesmo nome, o grande fluxo de migrantes vindos do Nordeste também tem a periferia como primeira morada. Ou seja, estas regiões estão sempre cheias do estranho, do estrangeiro, aquele cujo silêncio estabelece os sentidos. Como o próprio autor afirma, a intenção do linchamento não é a desordem, é, sim, restabelecer à comunidade uma ordem que se acreditava haver antes.

Orlandi traz em seu trabalho uma importante avaliação sobre a violência. Para a autora, ela "é causada pela falta de sociabilidade, pelo distanciamento produzido por relações sociais de segregação e distanciamento" (2016, p. 212). Podemos avaliar que tal distanciamento produzido pela segregação da cidade evita que certos sentidos circulem. Com isso, o silêncio sempre se faz significar e os sentidos não podem ser deslocados por falta de contato entre segregadores e segregados. 
A imputação da culpa ao linchado é resultado desse afastamento entre agressor e agredido. É impor por meio da agressão o sentido apreendido através da falta do Estado. É ele que falha ao não promover maior diálogo entre os sujeitos. E, quando o tribunal de rua está montado, não há espaço para o contraditório. Apenas é reafirmado o sentido inicial, aplicada a pena independentemente da culpa. O que se busca é reafirmar os sentidos já tidos, tanto para o linchado quanto para o local dos crimes que deram origem ao ato.

\section{REUNINDO AS ANÁLISES}

Para melhor compreender o que aqui foi exposto faremos um breve apanhado sobre o caso de linchamento de Fabiane Maria de Jesus. Para tal, usaremos o relato conforme contado por Furtado e Junior (2016). Conforme o apurado pelos pesquisadores, Fabiane foi linchada na comunidade Morrinhos 4, mas era moradora da comunidade Morrinhos 1, uma subdivisão do bairro. Seu linchamento teve início quando moradores de Morrinhos 4 viram-na saindo de um minimercado, em seguida, oferecendo uma fruta a uma criança que estava na porta do estabelecimento. Nesse momento alguém gritou que ela era a "bruxa da internet", fazendo menção ao retrato falado que vinha sendo divulgado por uma página de um noticiário local no Facebook. Na matéria, afirmava-se que estava à solta uma mulher que sequestrava crianças para realizar rituais de magia negra. Fabiane era evangélica e carregava uma bíblia de capa preta no momento do ataque. Algumas das pessoas que praticaram o ato chegaram a gritar que o livro que ela carregava seria uma bíblia satânica.

O linchamento teve início às $14 \mathrm{~h} 15$ de 3 de maio de 2014, e durou cerca de duas horas. "A vítima foi amarrada com arame, arrastada, espancada, agredida com uma roda de bicicleta e pedaços de pau" (FURTADO e JUNIOR, 2016). Após o ato, Fabiane foi jogada no mangue, onde foi encontrada e levada para o hospital. Ela ficou internada por mais dois dias, morrendo em 5 de maio.

Pela descrição do ato podemos observar tanto a questão do bode expiatório de Girard (1983) quanto aquilo que salienta Martins (2015) quando diz que a tentativa é de restabelecer a ordem. Observemos que Fabiane não era moradora do local onde foi atacada, sua comunidade era vizinha, e, portanto, não tinha conhecidos naquela área. Sendo assim, sua semelhança física com alguém que estava a desestabilizar o sentido de segurança que havia na comunidade e o fato de poder ser considerada uma estranha, portanto alguém que se poderia agredir sem maiores consequências, tornou-a um alvo fácil a ser expiado.

Há um outro fato interessante para ser ressaltado no relato da descrição feita do caso: Fabiane ter dado uma fruta a uma criança que estava em frente ao minimercado de onde saía foi o que deu início ao linchamento. Tal ação traz a memória dos contos de fada, onde a bruxa tenta atrair suas vítimas entregando-lhe algum presente. E mais diretamente o caso da Branca de Neve, figura que representaria a bondade e a inocência no conto infantil, assim como a figura da criança em nossa época, que recebeu uma maçã envenenada que a matou. A maçã também retoma a questão bíblica do pecado original 
cometido por Eva ao comer a maçã da árvore proibida ${ }^{3}$. Percebemos aqui como as memórias circulam em diferentes formações discursivas, com efeitos de sentido diferentes. Se numa formação discursiva dos contos de fada temos a bruxa como entidade sobrenatural, na formação discursiva do justiçamento popular temos a "bruxa da internet". Enquanto nos livros a bruxa tira o sono das crianças, em Morrinhos 4, a "bruxa da internet" pede uma ação imediata: linchamento.

Sendo assim, podemos considerar que uma das textualizações do discurso representado pela formação discursiva do justiçamento popular é a violência no corpo do linchado. Em outras análises feitas sobre o mesmo tema poderemos encontrar outras, como certos brados populares, por exemplo. Vale ressaltar que infligir estes mesmos ferimentos em outras formações discursivas, como a do machismo, significaria de outra forma e requereria uma nova análise. Afinal, seriam diferentes condições de produção.

\section{CONCLUSÃO}

Buscamos, nas linhas acima, mostrar que pela teoria da Análise de Discurso é possível compreender o ato do linchamento como uma tentativa de estabilização de sentidos que determinada sociedade tinha, através de gestos de interpretação.

Queremos lembrar que, como diz Pêcheux (1969), gestos são atos no nível simbólico. Quando eu junto gestos a interpretação, desloco o que diz Pêcheux para abarcar mais do que para ele eram os gestos (assobiar, jogar uma bomba numa assembléia, etc.). No modo como tomo a questão do gesto e o ligo a interpretação, estou dizendo que, na prática simbólica, produzimos gestos de interpretação, sendo estes, modos de interferir no mundo, através da prática simbólica que é a interpretação. Repito: a interpretação é uma prática (simbólica) em meio a outras práticas (sociais). (ORLANDI, 2010, p. 10)

Consideramos o linchamento como um discurso que faz circular certos sentidos e apaga outros. É “um modo de interferir no mundo, através da prática simbólica que é a interpretação". Para tanto recorremos à noção de ideologia como Pêcheux a descreve, não como apagamento, mas como processo que faz emergir certos sentidos. Ou como Orlandi (2008, p. 43-44) a considera, como uma injunção à interpretação. Para a autora, "o processo ideológico, no discursivo, está justamente nessa injunção a uma interpretação que se apresenta sempre como a interpretação. Esse é um dos princípios básicos do funcionamento da ideologia, apreendido pelo discurso" (idem, p. 44).

Com relação ao linchamento, tomamos a perspectiva de que seus ferimentos são como a textualização, não só do corpo banido do linchado (aquele que é considerado estranho), mas também da descrença na justiça, da exacerbação da violência, da falha da lei, fazendo com que signifique de determinada maneira. Tomamos como ponto de partida a compreensão de Orlandi sobre a textualização de corpos com piercings e tatuagens. Assim como no caso apontado por Orlandi, onde os piercings e tatuagens preenchem o silêncio e significam antes mesmo da fala, os ferimentos infligidos ao linchado fazem

\footnotetext{
${ }^{3}$ É importante ressaltar que não há informações sobre a maneira como agia a mulher cujo retrato falado foi divulgado (não se sabe se ela abordava as crianças com presentes ou qualquer outro objeto), nem mesmo foi confirmado se o retrato falado era de alguém que praticava sequestros.
} 
com que os sentidos que o linchador tem sobre a vítima se signifiquem antes que ela possa se significar através da língua.

Para finalizar, podemos concluir que o corpo banido, linchado, condenado, é um efeito do desarranjo do próprio corpo social e jurídico e que se textualiza, marca a hostilidade. Ao tratarmos por corpo banido o corpo do linchado, entendemos que ele está fora, um corpo expulso do jurídico, da lei, um corpo, portanto, que pode ser hostilizado, linchado, expurgado. Sendo assim, consideramos o linchamento como efeito, porque ele significa o corpo do outro como estrangeiro, como aquele que se pode deixar morrer ou, pior, se pode matar. Um corpo sem direitos. Um corpo condenado a significar pelos gestos de outros, sem possibilidade de se dar sentido, defender-se.

\section{REFERÊNCIAS}

BANDIDO é preso após roubar carro no Rio de Janeiro. 2016. Disponível em: http://noticias.r7.com/balanco-geral-manha/videos/bandido-e-preso-apos-roubar-carroe-cair-em-armadilha-no-rio-de-janeiro-27102016. Acesso em: 01. dez. 2016.

COSTA, Greciely Cristina da. Sentidos de milícia: entre a lei e o crime. Campinas: Editora da Unicamp, 2014.

CRIMINOSO é preso após roubar carro em Gravataí. 2016. Disponível em: http://www.oreporter.net/criminoso-e-preso-apos-roubar-carro-em-gravatai/. Acesso em dez. 2016.

FERREIRA, A.B. de H. Minidicionário da língua portuguesa. Rio de Janeiro: Nova Fronteira, 1993.

FOUCAULT, Michel. Microfísica do poder. São Paulo: Paz \& Terra, 2015.

Vigiar e Punir: história de violência nas prisões. Petrópolis: Vozes, 1987.

FREUD, S. Psicologia das massas e a análise do eu. Porto Alegre: L\&PM, 2013.

FURTADO, L. de S.; JUNIOR, W.F. O linchamento de Guarujá e a violência mimética de René Girard. Revista Iurisprudentia [Revista da Faculdade de Direito da AJES], v. 3, $\mathrm{n}^{\mathrm{o}}$. 5 . Disponível em: http://www.revistaiurisprudentia.com.br/arquivos/20150420211310.pdf. Acesso em nov. de 2016.

GIRARD, René. La violencia y lo sagrado. Barcelona: Editorial Anagrama, 1983.

HANSEN, Fábio. A noção de pré-construído e seus desdobramentos no processo criativo do discurso publicitário. 2010. Disponível em: http://seer.ufrgs.br/index.php/organon/article/view/28644/17323. Acesso em nov. 2016. 
HERBERT, Thomas. (1967). Observações para uma teoria geral das ideologias. RUA, 1, Campinas, 63-89, 1995.

MARTINS, J. de Souza. Linchamentos: a justiça popular no Brasil. São Paulo: Contexto, 2015.

ORLANDI, E.P. Discurso em Análise: sujeito, sentido, ideologia. Campinas: Pontes, 2016.

. Discurso e Texto: formulação e circulação dos sentidos. Campinas: Pontes, 2012. 2012.

. Interpretação: autoria, leitura e efeitos do trabalho simbólico. Campinas: Pontes,

A contrapelo: incursão teórica na tecnologia: discurso eletrônico, escola, cidade.

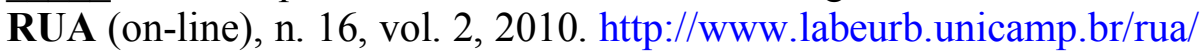

Terra à vista: discurso do confronto: velho e novo mundo. $2^{\mathrm{a}}$. ed. Campinas: Editora da Unicamp, 2008. 1997.

As formas do silêncio: no movimento dos sentidos. Campinas: Ed. da Unicamp,

PÊCHEUX, Michel. O papel da memória. Em: ACHARD, P. et. al. O papel da memória. Trad. Bras. $3^{\text {a }}$ ed. Campinas: Pontes, 2010.

Sobre os contextos epistemológicos da Análise de Discurso. Escritos, v. 4, 1999. Disponível em: http://www.labeurb.unicamp.br/portal/pages/pdf/escritos/Escritos4.pdf. Acesso em nov. de 2016.

ROBERTO, Maria Leda R. Efeitos de pré-construído em cartuns. 2005. Disponível em: http://anaisdosead.com.br/2SEAD/SIMPOSIOS/MariaLedaRRoberto.pdf. Acesso em 17. nov. 2016.

Artigo recebido em: janeiro de 2018.

Aprovado e revisado em: abril de 2018.

Publicado em: maio de 2018. 


\section{Para citar este texto:}

FERRAGUT, Guilherme. O linchado e a produção do corpo criminoso. Entremeios [Revista de Estudos do Discurso, ISSN 2179-3514, on-line, www.entremeios.inf.br], Seção Estudos, Programa de Pós-Graduação em Ciências da Linguagem (PPGCL), Universidade do Vale do Sapucaí (UNIVÁS), Pouso Alegre (MG), vol. 16, p. 229-242, jan. - jun. 2018

DOI: http://dx.doi.org/10.20337/ISSN2179-3514revistaENTREMEIOSvol16pagina229a242 